\title{
REPRESENTATIVE DEMOCRACY ACROSS LEVELS? NATIONAL PARLIAMENTS AND EU CONSTITUTIONALISM
}

\begin{abstract}
Davor Jančić*
Summary: This contribution analyses the meaning and practical application of the concepts of representative democracy and constitutionalism in relation to national parliaments within the European Union. A specific focus of investigation is the post-Lisbon function of national parliaments as conceptualised in a variety of models of EU constitutionalism. These models underline the importance of the independent roles of national parliaments by observing them not in the classic constellation of hierarchy but rather in that of heterarchy. However, there is as yet no sophisticated methodological approach for assessing the interactions between national parliaments and EU institutions and there is very little evidence of national parliamentarians performing as European actors. In order to test the theoretical premises, the article delves into the political praxis and examines the manner in which MPs and senators apply scrutiny instruments regarding a number of $E U$ dossiers that were the object of cross-level discussions within the frameworks of COSAC, the Barroso Initiative and the early warning mechanism. The objective of the inquiry is to test the hypothesis that national parliamentary scrutiny of EU decision making does not occur as an isolated domestic process but as a process that is interdependent with those unravelling at the EU level, and that such scrutiny has implications for the European Union's democratic legitimacy.
\end{abstract}

\section{Introduction: weaving national political actors into the EU decision-making playground}

Twenty years after the entry into force of the Maastricht Treaty, the democratic basis of the European Union has a new shape. With the entry into force of the Treaty of Lisbon on 1 December 2009, the operating system of the Union was reconfigured to involve traditional constitutional

\footnotetext{
"Assistant Professor, Institute of Constitutional and Administrative Law, Utrecht University, the Netherlands. This is a revised version of the paper presented in Boston, Massachusetts, at the 19th Conference of Europeanists organised by the Council for European Studies of Columbia University from 22 to 24 March 2012. The author is grateful to Professor Leonard Besselink, Dr Karolina Boronska-Hryniewiecka, François Randour and other participants on the panel for their very useful comments. The author would also like to thank two anonymous reviewers for their helpful and constructive remarks.
} 
actors that are typical of a full-blown national political community. Citizens have gained the right to initiate EU legislation under certain conditions and the national parliaments of the EU Member States have become the centrepiece of many contemporary constitutional discussions in Europe. ${ }^{1}$ The ink is still wet on the so-called Fiscal Treaty, ${ }^{2}$ signed on 2 March 2012 by all Member States except the United Kingdom and the Czech Republic. This Treaty, concluded outside the regular legal framework for the conclusion of EU Treaties and thus within an intergovernmental setting, ${ }^{3}$ yet again impacts on the status of national parliaments in the Union's juridico-political order.

This paper explores the EU concepts of representative democracy and constitutionalism in relation to the European portfolio of national parliaments and seeks to answer the question of whether these parliaments perform their rights and duties within the EU constitutional order, ie beyond the domestic confines of their competences. Within this portfolio, constitutional values such as political representation and accountability are key to positioning national parliaments on the Union's constitutional map and interpreting the meaning of their institutional functions within the EU construct.

Traditionally, states are structured hierarchically. After being invested by the electorate or by the representative body, the executive branch typically drafts and initiates legislation and guides its passage through the legislature. The executive then implements it and monitors the addressees' adherence to it. Yet with the creation of the European Union, a portion of domestic powers thereto exercised by national parliaments was delegated to EU institutions. Besides the Council of Ministers, which remains the decision-making powerhouse, one of these institutions is the EU's own parliament - the European Parliament. The claim to lawmaking authority thus became a challenge, almost an irritant causing disputes between the EU and its Member States, arousing national jealousies and forcing the introduction in the Treaties of the principle of subsidiarity and of the means to ensure its application. ${ }^{4}$ Already long before the introduction in the Lisbon Treaty of the early warning mechanism for the monitoring of subsidiarity compliance, a cross-level institutional

\footnotetext{
1 The citizens' initiative is laid down in Article 11(4) TEU, whereas the competence of national parliaments is summed up in Article 12 TEU.

2 The full name of this treaty is Treaty on Stability, Coordination and Governance in the Economic and Monetary Union.

3 Article 16 of this Treaty provides nevertheless that at most within five years of its entry into force, the necessary steps shall be taken to incorporate the substance of this Treaty into the EU legal framework.
}

4 See Article 5(3) TEU. 
forum had been established as early as 1989 under the name of COSAC, ${ }^{5}$ as a biannual conference gathering delegations of the European Affairs Committees of national parliaments and of the European Parliament. Furthermore, since even after the Lisbon Treaty the appointment of the Commission continues to be dominated by the European Council and the Council of Ministers rather than by the European Parliament, ${ }^{6}$ the idea of establishing a link between directly elected representatives of the Member States and the Commission became prominent as a vehicle of palliating the democratic deficit and was institutionalised in 2006 in the form of the so-called Barroso Initiative. ${ }^{7}$

After discussing the EU concept of representative democracy from a legal viewpoint, we analyse the relationship between national parliaments and the EU as inscribed in the Lisbon and Fiscal Treaties and as conceptualised in the most relevant theoretical models of EU constitutionalism. Thereafter, we present the existing forums of less formal interparliamentary cooperation across levels in the EU and, finally, examine the practical exercise of domestic parliamentary scrutiny of EU legislation from a more empirical perspective. With examples from practice engendered by COSAC, the Barroso Initiative and the early warning mechanism, we enquire whether the functions performed by national parliaments within these three mechanisms could be beneficial not only for the national legal orders but also for that of the European Union it-

5 This is the acronym derived from the French phrase Conférence des Organes Spécialisés dans les Affaires Communautaires.

6 Article 17(7) TEU reads: 'Taking into account the elections to the European Parliament and after having held the appropriate consultations, the European Council, acting by a qualified majority, shall propose to the European Parliament a candidate for President of the Commission. This candidate shall be elected by the European Parliament by a majority of its component members. If he does not obtain the required majority, the European Council, acting by a qualified majority, shall within one month propose a new candidate who shall be elected by the European Parliament following the same procedure. The Council, by common accord with the President-elect, shall adopt the list of the other persons whom it proposes for appointment as members of the Commission. They shall be selected, on the basis of the suggestions made by Member States, in accordance with the criteria set out in paragraph 3 , second subparagraph, and paragraph 5, second subparagraph. The President, the High Representative of the Union for Foreign Affairs and Security Policy and the other members of the Commission shall be subject as a body to a vote of consent by the European Parliament. On the basis of this consent the Commission shall be appointed by the European Council, acting by a qualified majority' (emphases added).

7 Though the importance of these links is mostly uncontested, it has been correctly observed that domestic elections are 'an extremely blunt instrument for citizens to express policy preferences', because of a variety of factors, including: (a) the lack of transparency in Council negotiations and the consequent difficulty of attaching responsibility to the participating national ministers; (b) the prevalence of domestic issues on the electoral agendas; (c) the fact that the most influential political parties rarely provide voters with clear alternative policy options concerning major questions related to EU governance. Pippa Norris, 'Representation and the Democratic Deficit' (1997) 32(2) European Journal of Political Research 275. 
self. We assess whether such cross-level forums may open a window of opportunity for a more democratically fit and transparent Union.

\section{Representative democracy in the EU and national parliaments: a legal perspective}

One novelty of the Lisbon Treaty is the assertion that 'the functioning of the Union shall be founded on representative democracy'. ${ }^{8}$ While citizens are directly represented in the European Parliament, the Member States are represented in the European Council by their Heads of State or Government and in the Council of Ministers by their governments. The EU founding treaties also provide that these state officials (presidents and prime ministers) are 'themselves democratically accountable to their national parliaments or to their citizens. ${ }^{9}$ The Treaties thereby endorse the agency chain that links the EU level to the national level of governmental authority. The EU hence relies on the accountability and legitimation mechanisms that are ingrained in the domestic constitutional orders. This testifies to a less autonomous understanding of the Union by the drafters of the Treaties, since the Union is not conceived of as the only source of public power but includes those of the Member States. In other words, the EU level alone cannot provide a panacea for all of the Union's democratic ills.

Concomitantly, the European Parliament has grown from a body representing 'the peoples of the states brought together in the Community'10 to a body representing 'the Union's citizens." ${ }^{11}$ The Union's and the European Parliament's representative claim henceforth focuses on the citizen rather than on the collective 'peoples'. The national boundaries between each and every European people belonging to the EU family have been 'erased' and they have merged into one entity consisting of citizens under one roof - that of the European Union. Again, a sense of civic 'togetherness' and political unity is sought. Yet the Union's citizens hold this appellation because they are citizens of one (or rarely more) of the Member States and, as such, they are represented in the parliament of that Member State. There is thus a degree of overlap between the representative claims of the European Parliament and its counterparts in the Member States. This raises the question of their mutual relationship and cooperation, which we address under Heading 6.

\footnotetext{
8 Article 10(1) TEU (emphasis added).

9 Article 10(2) TEU.

10 Former Article 189(1) TEC.

11 Article 14(2) TEU.
} 
Despite the possible expectation that the enhancement of the European Parliament would solve the bulk of the EU's democratic woes, it did not. In the eyes of Lindseth, representation by the European Parliament is not

constitutional representation on par with a national parliament, in the sense of the European Parliament being understood as the expression of the democratic will of a political community that sees itself as historically cohesive and capable of self-rule through a legislative body constituted for that purpose. [...] In this critical respect, the national parliaments remain the ultimate principals in the European system, while the European Parliament is fundamentally an agent. $^{12}$

The same view was espoused by the German Federal Constitutional Court (BVerfG) in its Lisbon Treaty judgment (Lissabon-Urteil), where it formulated a democracy solange of sorts, placing national parliaments of the Member States at the throne of EU legitimacy before the European Parliament for as long as the Union is founded on the principle of conferral. ${ }^{13}$ These sceptical views of the European Parliament's representative quality laid bare not only the fact that national parliaments have a role to play as regards the EU but also the hypothesis that this role is to be played within the EU. It is well known that national parliaments perform scrutiny activities related to the EU, ${ }^{14}$ but it is much less known whether they act with a view to contributing to a wider EU debate that would include appraising the action by EU institutions as such or whether they carry out scrutiny merely with a view to holding the national government to account without paying heed to the overarching institutional context of EU decision making. This hypothesis is put to the test under Heading 7.

Factors that led to EU constitutional solutions that incorporate domestic sources of authority include the facts: (a) that the Council of Min-

12 Peter L Lindseth, Power and Legitimacy: Reconciling Europe and the Nation-State (OUP 2010) 229 (emphasis in original).

13 Davor Jančić, 'Caveats from Karlsruhe and Berlin: Whither Democracy after Lisbon?' (2010) 16(3) Columbia Journal of European Law 355; Daniel Thym, 'In the Name of Sovereign Statehood: A Critical Introduction to the Lisbon Judgment of the German Constitutional Court' (2009) 46 CML Rev 1813.

14 See the many debates thereof in: Gavin Barrett (ed), National Parliaments and the European Union: The Constitutional Challenge for the Oireachtas and Other Member State Legislatures (Clarus Press 2008); Philipp Kiiver (ed), National and Regional Parliaments in the European Constitutional Order (Europa Law Publishing 2006); Andreas Maurer and Wolfgang Wessels (eds), National Parliaments on Their Ways to Europe: Losers or Latecomers? (Nomos Verlagsgesellschaft 2001); John O'Brennan and Tapio Raunio (eds), National Parliaments Within the Enlarged European Union: From Victims of Integration to Competitive Actors? (Routledge 2007); Olaf Tans et al (eds), National Parliaments and European Democracy: A Bottom-up Approach to European Constitutionalism (Europa Law Publishing 2008). 
isters is collectively unaccountable but retains pre-eminence in decisionmaking processes despite its ministerial and executive structure; and (b) that the European Parliament not only still struggles to assert its legislative power but continues to possess only rudimentary powers in appointing the Commission President, European Council President and other key EU functionaries. One of these solutions was to approximate national parliaments to the Union's legislative and controlling processes. As one author put it, 'if the EU institutions have such difficulties in making a qualitative leap forward, why not strengthen the existing national basis of legitimacy', especially given that 'national parliaments play their part mainly on the executive side of representation, by providing a democratic base for their governments to act within the Council'. ${ }^{15}$ That is why in general terms:

When an international treaty begins to boast an integrated legal system conferring rights and creating duties on all public and private persons altogether new questions of legitimacy come to the fore which cannot be resolved by reference to the ordinary legitimating mechanisms of international law. ${ }^{16}$

It is therefore critical to devise new methods of securing legitimacy for the European project and its future success, not least through parliamentary means. As the following two headings show, to achieve this it is necessary to turn to the Member States and their institutions for assistance.

\section{National parliaments in the Lisbon Treaty: an insufficient stimulus?}

Ever since the Maastricht Treaty, through the declarations and protocols appended thereto, national parliaments have been assuming more independent roles within the EU. It was the rise of the principle of subsidiarity that sparked the closer inclusion of national parliaments in European affairs. ${ }^{17}$

In the wake of the Lisbon Treaty, the most encompassing task of national parliaments is to "contribute actively to the good functioning of the

\footnotetext{
15 Karlheinz Neunreither, 'Political Representation in the European Union: A Common Whole, Various Wholes or Just a Hole?' in Karlheinz Neunreither and Antje Wiener (eds), European Integration after Amsterdam: Institutional Dynamics and Prospects for Democracy (OUP 2000) 144-145.

16 Joseph HH Weiler and Joel P Trachtman 'European Constitutionalism and its Discontents' (1996-1997) 17 Northwestern Journal of International Law and Business 356-357.

17 Berthold Rittberger, Building Europe's Parliament: Democratic Representation Beyond the Nation-State (OUP 2005) 194.
} 
Union', ${ }^{18}$ which itself, as we have seen, shall be based on representative democracy. Parliamentarians are to do so above all by policing the EU institutions' respect for this principle by sending them reasoned opinions on incoming EU legislation that violates subsidiarity and, if necessary, by seizing the Court of Justice. ${ }^{19}$ Yet the practical fulfilment of this task is fraught with difficulties in dissociating subsidiarity from proportionality and in achieving the high thresholds imposed by the Treaties for the MPs' collective action to bear fruit. This is why Von Bogdandy referred to the early warning mechanism as a 'subordinate safeguard mechanism', which 'invites national parliaments to dress up any political concern in the guise of a subsidiarity claim. ${ }^{20} \mathrm{He}$ acknowledges, however, the centrality of national parliaments in legitimising primary EU law. In his view, 'in the current constitutional situation there is a clear dominance of the line of legitimacy from the national parliaments.' ${ }^{21}$ This he underpins by reliance on the Treaty provision that involves these parliaments in the ordinary treaty amendment procedures (by means of approval) and simplified treaty amendment procedures (by means of opposition). ${ }^{22}$

Given the obstacles in applying the new rights of national parliaments and the fact that these parliaments continue to be withdrawn from the European legislative process stricto sensu, one is tempted to question the sufficiency of EU provisions to genuinely constitute the engine of national parliamentary engagement in EU affairs. This state of affairs is further exacerbated by the sovereign debt crisis in the Eurozone, which has led to the unprecedented empowerment of the executive branch. Many crucial decisions regarding the single currency and budgetary policy, which lie at the heart of national parliamentary involvement, are decided by the Heads of State or Government gathering in the European Council and Eurozone summits with ever increased frequency. This brings home the idea that domestic forums of democratic representation, in the first place national parliaments, ought to find ways of keeping the EU's action in check, regardless of the provisions foreseen in the Treaties establishing or deepening the Union. This also means that their own disempowerment ought to occupy the centre stage of the EU political debate.

\footnotetext{
18 Article 12 TEU.

19 Articles 7 and 8 of Protocol no 2 on the Application of the Principles of Subsidiarity and Proportionality. See the most recent analysis of the early warning mechanism in Philipp Kiiver, The Early Warning System for the Principle of Subsidiarity: Constitutional Theory and Empirical Reality (Routledge 2012).

20 Armin von Bogdandy and Jürgen Bast 'The Federal Order of Competences' in Armin von Bogdandy and Jürgen Bast (eds), Principles of European Constitutional Law (Hart Publishing 2010) 303-304.

${ }^{21}$ Armin von Bogdandy, 'Founding Principles' in Bogdandy and Bast (n 20) 50.

22 Article 48 TEU.
} 


\section{Moving into the post-Lisbon era: the euro crisis and a further degradation of national parliaments?}

The Lisbon Treaty reforms notwithstanding, for national parliamentarians EU matters remain an 'alien territory' that is not 'theirs'. ${ }^{23}$ It is not astonishing, therefore, that certain authors are sceptical of the national parliaments' role in European matters. ${ }^{24}$ Yet what precisely is 'theirs'?

The need for swift fiscal consolidation in the Union, itself riven by the Member States' budget deficits and rising public debts, potentially jeopardises the position of national parliaments. In this respect, the European Council of March 2011 analysed the policies likely to address the EU's fiscal problems and mandated 'full involvement of national parliaments' and 'full respect of the prerogatives of national parliaments'. ${ }^{25}$

The resulting EU Fiscal Treaty, which is set to enter into force no sooner than 1 January 2013, obliges the signatories to give effect in their national laws to the rules set out therein through binding and permanent provisions, preferably those of a constitutional nature, which will guarantee that they will be fully respected and adhered to throughout the domestic budgetary processes. This Treaty also explicitly lays down that the correction mechanism envisaged in the event of significant deviations from the agreed country-specific medium-term budgetary targets 'shall fully respect the prerogatives of national parliaments'. ${ }^{26}$

The signatories of the Treaty are furthermore under the duty to take the necessary actions and measures in all the areas that are essential to the proper functioning of the euro area, especially those that foster competitiveness and employment as well as those that contribute to the sustainability and stability of public finances. ${ }^{27}$ Insofar as these measures are to be adopted by national parliaments, they play a vital role in resuscitating the Eurozone. European leaders, policy makers, lobbyists, academics and citizens are keeping a close watch on the actions of national parliaments, since it is the representatives democratically elected

\footnotetext{
23 Philipp Dann, 'The Political Institutions' in Bogdandy and Bast (n 20) 269.

24 See for instance Tapio Raunio, 'National Parliaments and the Future of European Integration: Learning to Play the Multilevel Game' in Joan DeBardeleben and Achim Hurrelmann (eds), Democratic Dilemmas of Multilevel Governance: Legitimacy, Representation and Accountability in the European Union, (Palgrave Macmillan 2007); Philipp Kiiver, National Parliaments in the European Union: A Critical View on EU Constitution-Building (Kluwer Law International 2006).

25 European Council, Meeting of 24-25 March 2011, Presidency Conclusions, point 6 on p 3 and Annex I on p 19.

26 Article 3(2) EU Fiscal Treaty.

27 Article 9 EU Fiscal Treaty.
} 
by the taxpayers who enjoy the power of the purse. Besides deciding on national budgets, these representatives are the ones who approve bailouts of the defaulting Eurozone economies and who adopt laws whose effect may well reverberate and affect markets, not solely in the Eurozone but across the globe.

Moreover, the Fiscal Treaty makes a reference to the Lisbon Treaty Protocol on the role of national parliaments and states that it is up to the European Parliament and national parliaments jointly to determine the organisation of a conference of representatives of their respective committees that are in charge of budgetary policies and other matters arising from this Treaty. ${ }^{28}$ Interparliamentary cooperation is thus extended to the fiscal area and some regard this as a case in favour of reinstating the Assizes, which was a one-off meeting of MPs and MEPs that failed to continue beyond its debut in $1990 .^{29}$

Another important international agreement was signed on 11 July 2011 by the finance ministers of the seventeen Eurozone Member States. The Treaty establishing the European Stability Mechanism (ESM) creates a permanent international rescue funding institution called, as the treaty name suggests, the European Stability Mechanism. This institution succeeds the existing two temporary bailout mechanisms, the European Financial Stability Facility and the European Financial Stabilisation Mechanism. Upon the ratification of the treaty, this new institution will provide financial assistance to the Eurozone Member States that experience or are threatened by severe financing problems, but only if strict predetermined conditions are fulfilled and if such assistance is indispensable to safeguard the financial stability of the euro area as a whole and of its Member States. ${ }^{30}$ Unlike the Fiscal Treaty, which addresses the function of national parliaments, the ESM Treaty only provides that the Board of Governors of the ESM shall make the institution's annual report accessible to national parliaments. ${ }^{31}$ No active participation by these parliaments is foreseen nor is any consequence attached to possible ensuing assessments of these reports in domestic parliamentary chambers.

Against this background, one wonders about the effect of these developments on national parliaments. Does the Eurozone crisis reinforce or further aggravate the already shaky position of national parliaments in the European Union? Recent pronouncements thereon by the Euro-

\footnotetext{
28 Article 13 EU Fiscal Treaty.

29 Ruth Fox, 'Europe, Democracy and the Economic Crisis: Is It Time to Reconstitute the “Assises"?' (2012) 65(2) Parliamentary Affairs 463.

30 Articles 3 and 12 of the Treaty establishing the European Stability Mechanism.

31 Article 30(5) of the Treaty establishing the European Stability Mechanism.
} 
pean Council President, Herman Van Rompuy, serve as a fertile starting point. In his speech at Humboldt University on 6 February 2012, Van Rompuy highlighted that the ongoing crisis fortifies the Union and brings to the fore the interdependence and co-responsibility among the Member States, its leaders and institutions, including parliaments:

Sixty years of integration has taught us that Europe is not built by dissolving Member States, but by infusing them ever more deeply... what we are currently going through is not a 'renationalisation of European politics', no, it is the 'Europeanisation of national political life'...The need for national money and therefore the involvement of national leaders and parliaments is simply a fact...Within this new division of labour, the national parliaments fully keep their budgetary sovereignty (at least as long as national policies do not threaten the financial stability of the euro itself!). Nevertheless there is some uneasiness among national politicians about the EU's new tasks... the feeling of co-responsibility isn't felt as strongly in national parliaments as it could be...Every national MP should therefore take an interest in talking to fellow parliamentarians in Strasbourg and in other member states...In meetings of the European Council, one feels the presence of all these parliaments...Many national leaders, in our discussions, refer to the position of their parliament, to defend specific amendments...Europe needs not only political action, but also positive attitudes towards its task. Particularly from its political representatives. ${ }^{32}$

Three weeks later, at an interparliamentary meeting on the European Semester, ${ }^{33}$ Van Rompuy reiterated that:

Via national leaders and governments, national parliaments have also become more implicated than ever in the day-to-day business of the Eurozone...Decisions by one national parliament - be it in Germany or Ireland, in Slovakia or Portugal - are watched all over Europe. Maybe not formally speaking, but at least politically speaking, all national parliaments have become, in a way, European institutions. This is political interdependence: the decisions of one affect all...As an outsider, I sometimes have the impression that the European Parliament and the national parliaments live in different worlds: the one always pushing for more integration, the others focusing on domestic issues and pulling the brakes. That is why it is important to understand each other's perspective!...Here the old slogan of the three musketeers applies: 'All for one; one for all!' It

32 Speech at the Humboldt University, Walter Hallstein Institute for European Constitutional Law, speech no EUCO 21/12, Berlin.

33 See below under Heading 6. 
is the responsibility of the parliaments to adapt themselves to this situation. ${ }^{34}$

Are we therefore moving towards a new type of Union in which the essential segments of national sovereignty are debunked? Suffice it to recall the July 2009 judgment of the German Federal Constitutional Court on the Lisbon Treaty. In taking a stance that sovereignty is a divisible concept, the BVerfG ruled that, along with certain other competences, ${ }^{35}$ the fiscal ones represent 'especially sensitive' fields that form the very core of state sovereignty. ${ }^{36}$ This approach, although much criticised in academic circles, ${ }^{37}$ exposes the fact that the Fiscal Treaty and the EU's sovereign debt crisis pose a new challenge not only for the executive but also for national parliaments as the EU steps into what most Member States would consider the nucleus of their legal independence and sovereignty.

In a similar vein, in September 2011 the BVerfG handed down another judgment in this regard. ${ }^{38}$ Three constitutional complaints that were directed against the Monetary Union Financial Stabilisation Act, which approves the provision of financial aid to Greece, and against the Act Concerning the Giving of Guarantees in the Framework of a European Stabilisation Mechanism, which refers to the rescue package, were rejected. These two statutes were found not to violate the right of the Bundestag to adopt the budget and control its implementation by the Federal Government. They were ruled compatible with Article 38 of the German Basic Law, which enshrines the right of eligible German citizens to elect members of the Bundestag. Yet the latter statute was found constitutional only on the condition that it is interpreted consistently with the Basic Law (Grundgesetz), which means that before giving any financial guarantees the Federal Government is obligated to obtain prior approval from the Bundestag's Budget Committee. Here we find another instance of a domestic parliament being defined as a bulwark against encroachment by the Union into the national sovereignty of a Member State, in this case the Member State that is the largest contributor to the European Stability Mechanism. This ruling is in harmony with BVerfG's

\footnotetext{
34 Speech during the Interparliamentary Meeting on the European Semester for Economic Policy Coordination, doc no EUCO 31/12, Brussels, 27 February 2012.

35 Those related to criminal law, use of force, social policy, family law, education systems and religion.

36 Jančić (n 13) 354.

${ }^{37}$ Daniel Halberstam and Christoph Möllers, 'The German Constitutional Court Says "Ja zu Deutschland!"' (2009) 10 German Law Journal 1241 and 1249; Christoph Schönberger, 'Lisbon in Karlsruhe: Maastricht's Epigones at Sea' (2009) 10 German Law Journal 1201 and 1209.

38 BVerfG, Judgment no 2 BvR 987/10 of 7 September 2011.
} 
previous case law, which has constantly underlined the importance and primacy of the German national parliament in legitimising EU integration.

Evaluating the crisis-induced role of national parliaments in the post-Lisbon period is not a straightforward task. On the one hand, these parliaments have been brought into the limelight of EU decision making and have been called upon to keep the Eurozone afloat, which they do by performing the legislative and budgetary functions as direct popular representatives of the citizens. They also do that by controlling the activity of the national governments in the many ongoing negotiations about the future of the euro. On the other hand, they act under enormous political pressure to adopt the measures recommended by EU institutions, so that their room for manoeuvre is politically, albeit not legally, restricted. In a situation where every day of inaction means greater debt, this pressure is more than tangible and threatens to tie the hands of national parliaments in the spirit of what Van Rompuy termed 'co-responsibility'. This politically constraining factor of parliamentary activity in European affairs is not novel, however. It has been present ever since the foundation of the Communities, whereby parliaments bore the heavy burden of approving the deals already made by national governments during intergovernmental conferences.

What is new about the national parliaments' position in the circumstances of the present crisis is that it is no longer the purely legislative and controlling functions that are at stake, but rather the function that is most fundamentally inherent in the notion of parliamentary representation - that of budgetary authority. It is debatable nonetheless to what extent this power is still 'theirs' and whether this development is ephemeral and limited to the crisis or whether it will give rise to a more permanent alteration, or blurring rather, of the competence boundaries between the Union and the Member States.

\section{EU constitutionalism and national parliaments: alternatives for hierarchy?}

Theoretical attacks on the understandings of the European Union as a constitutional entity that is supreme and hierarchically superior to the Member States have been made for some time. ${ }^{39}$ One way to conceive of this evolution was conveniently reported by Weiler and Trachtman some fifteen years ago:

39 Leonard Besselink, A Composite European Constitution (European Law Publishing 2007) 8-9. 
European constitutionalism must depend on a common law-type rationale, one which draws on and integrates the national constitutional orders, and the constitutional discourse in Europe must be conceived of as a conversation of many actors in a constitutional interpretative community rather than a hierarchical structure [...]. ${ }^{40}$

In most general terms, postnational pluralism has been posited as an alternative to traditional, hierarchical, state-derived constitutionalism. In his recent account, Krisch held that:

Postnational pluralism recognises the blurred separation of layers of law but does not seek to reorganise them in an overarching legal framework, as does constitutionalism. It envisages a heterarchical structure in which the interaction of different layers is not ultimately determined by one legal rule but influenced by a variety of (potentially conflicting) norms emanating from each of the layers. Between the different layers, there is no common point of reference in law; their relationship is fundamentally open and depends, in large part, on political factors. ${ }^{41}$

In the words of another author, in the European Union '[t]here is no uniform legal order, ie a single hierarchy of rules and single hierarchy of institutions. ${ }^{42}$ It is this multiplicity of legal and constitutional sources that triggers our problematisation of the European role of national parliaments. Other constitutionalist models, which we explain below, offer a more concrete conceptualisation of the role of national parliaments in the material EU constitution.

A sibling of multilevel governance, Pernice's multilevel constitutionalism, implies that the European constitution consists of both national constitutions and EU Treaties. In such a constellation, EU and MemberState institutions are intertwined and dependent on each other, even though they belong to different, formally separate levels of government. ${ }^{43}$ In a sense, national constitutional actors act as 'European agencies'. ${ }^{44}$ National parliaments hence feature as European parliaments that are

\footnotetext{
40 Joseph HH Weiler and Joel P Trachtman, 'European Constitutionalism and its Discontents' (1996-1997) 17 Northwestern Journal of International Law and Business 391. See the most recent discussions in Gráinne de Búrca and Joseph HH Weiler (eds), The Worlds of European Constitutionalism (CUP 2012).

${ }^{41}$ Nico Krisch, Beyond Constitutionalism: The Pluralist Structure of Postnational Law (OUP 2010) 298.

42 Pavlos Eleftheriadis, 'The Standing of States in the European Union' in Nicholas Tsagourias (ed), Transnational Constitutionalism: International and European Models (CUP 2007) 69.

43 Ingolf Pernice, 'Multilevel Constitutionalism and the Treaty of Amsterdam: European Constitution-Making Revisited (1999) 36 CML Rev 707 and 710.

44 Pernice (n 43) 718.
} 
indispensable to the Union, although their role in EU decision making is complementary to that of the European Parliament. ${ }^{45}$ However, the concept of levels has not remained unchallenged. For instance, Cananea held that levels are a 'biased metaphor' that implies hierarchy. ${ }^{46}$

The same has also been held by Besselink, ${ }^{47}$ who offered a competing model, that of composite or polycentric constitutionalism. He, too, relies on constitutional interdependence between EU and national institutions within an overarching composite constitutional order that keeps these two components together in a coherent fashion. ${ }^{48}$ This polycentric view of interinstitutional relations in the Union hypothesises that boundaries between the European and national levels do not exist. National parliaments thus freely interact with EU institutions as their immediate counterparts. Indicators of such parliamentary action include situations where: parliaments request and receive information on draft EU legislation directly from the Commission; representatives of the Commission visit parliaments to explain their policies; national ministers are asked to justify not only the government's but also the Union's legislative plans and programmes; ${ }^{49}$ parliaments not merely defend the position to be represented in the Council but also put forth political views or ideas that, although communicated to the minister, are addressed to EU institutions. ${ }^{50}$ Yet, as Kiiver emphasised, the mutual interdependence between the activities of the parliaments of different Member States is not self-evident, as parliaments primarily focus on the action of their own governments in EU matters and pay little heed to similar occurrences in other Member States. ${ }^{51}$

A further theoretical concretisation of the relations between Europe's parliaments finds its shape in what Crum and Fossum have called

\footnotetext{
45 Ingolf Pernice, "The Role of National Parliaments in the European Union," (2001) Walter Halstein Institute Paper 5/01, 17.

46 Giacinto della Cananea, 'Is European Constitutionalism Really “Multilevel”?' 2010 70(1) Heidelberg Journal of International Law 307.

47 Besselink (n 39) 6.

48 Leonard Besselink, 'Case C-145/04, Spain v. United Kingdom, judgment of the Grand Chamber of 12 September 2006; Case C-300/04, Eman and Sevinger, judgment of the Grand Chamber of 12 September 2006; ECtHR (Third Section), 6 September 2007, Applications Nos 17173/07 and 17180/07, Oslin Benito Sevinger and Michiel Godfried Eman v. the Netherlands (Sevinger and Eman)' (2008) 45 CML Rev 803.

49 Besselink (n 39) 18-19.

50 Leonard Besselink, 'National Parliaments in the EU's Composite Constitution: A Plea for a Shift in Paradigm' in Philipp Kiiver (ed), National and Regional Parliaments in the European Constitutional Order (Europa Law Publishing 2006) 119 and 125.

51 Philipp Kiiver, 'European Scrutiny in National Parliaments: Individual Efforts in the Collective Interest?' in John O'Brennan and Tapio Raunio (eds), National Parliaments within the Enlarged European Union (Routledge 2007) 75-76.
} 
the 'multilevel parliamentary field'. In this field, the European Parliament and national parliaments are rightly observed as sharing the vocation of political representation..$^{52}$ The most innovative aspect of their analysis is the introduction of role perceptions that structure and guide interparliamentary interaction. These are conceived through the notion of 'habitus', which refers to the mental dispositions and presuppositions of the participating actors. The European and national parliamentarians share the same role as parliamentarians and the query is specifically targeted at whether MPs and MEPs of a given Member State reinforce each other or compete for authority. ${ }^{53}$

In sum, as Hofmann underscores, a fundamental feature of parliamentary representation in the multilayered European Union is cooperation between parliamentary forums. ${ }^{54}$ Developing closer ties across levels could lead to coordinated approaches to legislation and to the implementation of EU norms. ${ }^{55}$ The importance of these informal channels of national parliamentary involvement in European affairs lies in the argument that 'even without a direct representation of national parliamentarians in EU decision making, national and sub-national parliaments may add to the legitimacy of European governance in a variety of ways'. ${ }^{56}$ Many other commentators have also advocated a more direct implication of national parliaments in EU policy and decision making. ${ }^{57}$

\section{Interparliamentary cooperation across the EU and national levels}

Whereas interparliamentary cooperation in the EU is encouraged through COSAC, the national and European parliaments are neverthe-

\footnotetext{
52 Ben Crum and John E Fossum, 'Multilevel Parliamentary Field: A Framework for Theorising Representative Democracy in the EU' (2009) 1(2) European Political Science Review 252 and 260.

53 Crum and Fossum (n 52) 262-263.

54 Herwig CH Hofmann, 'Parliamentary Representation in Europe's System of Multilevel Constitutions: A Case Study of Germany' (2003) 10(1) Maastricht Journal of European and Comparative Law 63.

55 Hofmann (n 54) 62.

56 Hofmann (n 54) 65.

57 See Tapio Raunio, 'National Parliaments and European Integration: What We Know and Agenda for Future Research' (2009) 15(4) Journal of Legislative Studies 317; Luc Verhey, 'Political Accountability: A Useful Concept in EU Inter-institutional Relations' in Luc Verhey et al (eds), Political Accountability and European Integration (Europa Law Publishing 2009) 68; John O’Brennan and Tapio Raunio, 'Conclusion: National Parliaments Gradually Learning to Play the European Game' in John O'Brennan and Tapio Raunio (eds), National Parliaments Within the Enlarged European Union: From Victims of Integration to Competitive Actors? (Routledge 2007) 273; Olaf Tans, 'Conclusion: National Parliaments and the European Union: Coping with the Limits of Democracy' in Tans (n 14) 242; Asteris Pliakos, 'National Parliaments and the European Union: Necessity of Assigning a Supranational Role' (2007) 19(3) European Review of Public Law 778.
} 
less free to decide how to organise and promote effective and regular mutual dialogue. ${ }^{58}$ Outside the explicit framework of the Treaties, a plethora of interparliamentary meetings have been organised..$^{59}$

The Conference of Speakers, first held in 1963 in Italy, is convened annually to debate topical issues of European integration and parliamentary supervision. For instance, the gathering of this Conference held in April 2011 decided that the existing meetings of COFAC (Conference of Foreign Affairs Committees) and CODAC (Conference of Defence Affairs Committees) would be replaced by an Interparliamentary Conference for the Common Foreign and Security Policy (CFSP) and the Common Security and Defence policy (CSDP), which would invite the High Representative to appear before it and which would be entitled to adopt non-binding conclusions by consensus. ${ }^{60}$

Joint parliamentary meetings are co-chaired by the Speakers of the European Parliament and of the national parliament of the Member State holding the EU Presidency. These meetings focus on areas where the Union does not legislate but nonetheless exercises important decisionmaking powers, such as the Lisbon Strategy, CFSP and CSDP, economic and monetary policy, enlargement, energy policy and climate change as well as the more general 'Future of Europe' themes. The objective of this forum is not to formulate common positions of parliamentarians but to promote strengthened parliamentary oversight of intergovernmental and non-legislative EU decisions. The impression of the present author, who personally attended one of these meetings, is that joint parliamentary meetings provide primarily an opportunity for parliamentarians to state the prevailing positions of their parliaments and to exchange information, which mostly occurs informally on the margins of the often vague and overly generalised discussions in the plenary sessions. ${ }^{61}$

Interparliamentary committee meetings with national parliaments represent another format of cooperation among EU parliaments. Unlike joint parliamentary meetings, interparlamentary committee meetings centre principally on EU policies decided by the ordinary legislative procedure, in which the European Parliament plays a co-equal role with

\footnotetext{
58 Articles 9 and 10 of Protocol no 1 on the Role of National Parliaments in the European Union. This protocol originates in the Protocol bearing the same name that was attached to the Amsterdam Treaty in 1997.

59 See especially the European Parliament's website <www.europarl.europa.eu/webnp/ $\mathrm{cms} / \mathrm{lang} / \mathrm{en} / \mathrm{pid} / 3$;jsessionid=DA626D97129515A6038F4BF26803F025 > accessed 6 March 2012.

60 Conference of Speakers, Meeting of 4-5 April 2011, Presidency conclusion no 5.

${ }_{61}$ Observations from the Joint Parliamentary Meeting on the Western Balkans 'Achieving the European Perspective for South East Europe' which took place in Brussels from 26 to 27 May 2008.
} 
the Council of Ministers. The purpose of these gatherings is to spur the exchange of views between MPs and MEPs and, consequently, to influence the position of the European Parliament in the legislative process. They are organised at the initiative of the relevant committees of the European Parliament, who invite their counterparts in national parliaments. For example, the meeting held on 27-28 February 2012 addressed the so-called 'European Semester for Economic Policy Coordination', a six-month cyclical period which, since 2011, is set to run every year with the aim of coordinating at the EU level the Member States' budgetary, macroeconomic and structural policies. The aim is to allow the Member States to take EU considerations into account at an early stage of their national budgetary processes.

Joint committee meetings are essentially the same as joint parliamentary meetings, except that they take place at the level of specialised committees of the national and European parliaments. In addition, numerous ad hoc committee-to-committee meetings between the European Parliament and national parliaments are organised at the initiative of the former or the latter.

Structural parliamentary reforms are another significant catalyst of cross-level interaction. These include the establishment of a Directorate for relations with national parliaments within the European Parliament; the empowerment of European Affairs Committees of national parliaments; an increased involvement of sectoral committees in the scrutiny of EU policies; the appointment of liaison officers, advisers and administrators within national parliaments; the appointment of permanent representatives of national parliaments (so-called 'antennas') in Brussels and basing them on the premises of the European Parliament, etc. These channels of a more informal collaboration, though less visible to the public, may substantially contribute to a seamless flow of information between clerks and persons in charge of the dossiers in the EU legislative pipeline.

It could thus be held that the Lisbon Treaty novelties and the successive changes in the domestic competences of Member-State parliaments represent an increasingly strong mutual interrelation between national institutions and European institutions, and, as a consequence, between national constitutional law and European law in the field of organisational law'. ${ }^{62}$ Still, despite these enhancements, there exist solid reasons to further incentivise the interaction between the European Parliament and national parliaments in EU decision making. On the one hand, it has been argued that once decisions are taken at the suprana-

62 Christoph Grabenwarter, 'National Constitutional Law Relating to the European Union' in Bogdandy and Bast, Principles of European Constitutional Law (n 20) 116. 
tional level, both political control and representation must also happen at that level, because decisions taken intergovernmentally are democratically counterbalanced by the unanimity rule, which affords the Member States the right of veto and enables national parliaments to exert some degree of influence through a stricter control of the government. 'It is in this respect', the argument goes, 'that the European Parliament has a unique function that cannot be fulfilled by national parliaments'. ${ }^{63}$ On the other hand, national parliaments are unique inasmuch as they are the only institutions that are entitled to hold individual Council members to account for their actions at the EU level. ${ }^{64}$

\section{Political practice examined: any heterarchy in sight?}

By sifting through the practice arising from COSAC subsidiarity checks, the political dialogue within the framework of the Barroso Initiative and the early warning mechanism, we seek to determine the state of affairs in the cross-level dialogue between domestic legislatures and EU institutions. Heterarchy is understood here as a framework that affords national parliaments an alternative channel of information and potential influence in EU affairs that analytically decouples them from the traditional constitutional linkage with their governments. The influence, instead, is refocused at the EU level itself. This is a crucial aspect, because the utility and effectiveness of national parliamentary scrutiny as a technique for legitimising EU decision making is not merely a matter of Treaty rights but also of 'the informal behaviour of supranational institutions as well as their perceptions of the democratic needs of integration'. ${ }^{65}$

Indeed, instances where national parliaments liaise or act interdependently with EU institutions outside the existing cooperative frameworks, ie as a matter of scrutiny or legislative business of each individual parliament, are rare and mainly occur where issues deliberated at the EU level arouse great national interest, jeopardise it or explicitly conflict with it. ${ }^{66}$ We therefore zoom in on the actual practice stemming from the

\footnotetext{
63 Jacques Thomassen and Hermann Schmitt, 'In Conclusion: Political Representation and Legitimacy in the European Union' in Hermann Schmitt and Jacques Thomassen (eds), Political Representation and Legitimacy in the European Union (OUP 1999) 256.

64 Leonard Besselink and Brecht van Mourik, The Roles of the National Parliament and the European Parliament in EU Decision-Making: The Approval of the Lisbon Treaty in the Netherlands' (2009) 15(3) European Public Law 316.

65 Lindseth (n 12) 243.

${ }^{66}$ An excellent example thereof is the cross-level institutional interdependence between the adoption of the so-called Loi Hadopi in France and the adoption in the same period of the EU telecoms reform package. These two dossiers contained conflicting provisions, which sparked intricate relationships across the EU and French levels of governance. See more in
} 
operation of the existing forums for direct cross-level interinstitutional dialogue: (a) between national parliaments and the European Parliament (COSAC); and (b) between national parliaments and the Commission (the Barroso Initiative and the early warning mechanism).

\subsection{COSAC: marshalling interparliamentary coordination}

\subsubsection{Origin and functioning of COSAC}

The interparliamentary forum known as COSAC is the brainchild of Laurent Fabius, the then President of the French Assemblée nationale, who proposed its creation at the Conference of Speakers in Madrid in May 1989 with a view to establishing closer ties with Community policy making at a time when the double mandate of national parliamentarians had been cancelled in many Member States for a decade. ${ }^{67}$

Ever since, twice a year, six-member delegations from national parliaments have been joined by six MEPs in the parliament of the Member State holding the Presidency of the Council to discuss topics of common interest and exchange information and best practice on current scrutiny business. ${ }^{68}$

COSAC was formally recognised only in 1997 in a protocol attached to the Amsterdam Treaty. It was then agreed that COSAC could send to EU institutions any contributions on legislative proposals or initiatives, in particular those related to the Area of Freedom, Security and Justice, the application of subsidiarity and questions regarding fundamental rights. However, these contributions could neither bind national parliaments nor prejudge their position. ${ }^{69}$ The Lisbon Treaty added in 2007 that COSAC may organise interparliamentary conferences on specific topics, such as on CFSP and CSDP. ${ }^{70}$ As we have seen, the Fiscal Treaty proposes the organisation of such conferences in the budgetary field, too.

\footnotetext{
Davor Jančić, 'The European Political Order and Internet Piracy: Accidental or Paradigmatic Constitution-shaping?' (2010) 6(3) European Constitutional Law Review 430.

67 Lord Tordoff, 'The Conference of European Affairs Committees: A Collective Voice for National Parliaments in the European Union' (2000) 6(4) Journal of Legislative Studies 1.

68 Morten Knudsen and Yves Carl, 'COSAC - Its Role to Date and Its Potential in the Future' in Gavin Barrett (ed), National Parliaments and the European Union: The Constitutional Challenge for the Oireachtas and Other Member State Legislatures (Clarus Press 2008) 475.

69 Points 4-7 of the Protocol on the Role of National Parliaments in the European Union attached to the Amsterdam Treaty.

70 Articles 9-10 of the Protocol on the Role National Parliaments in the European Union attached to the Lisbon Treaty.
} 
Over the years, COSAC has grown into a coordinator of national parliamentary activities in EU matters. ${ }^{71}$ It played a vital role in setting in motion the national parliaments' subsidiarity checks, although these have been discontinued upon the entry into force of the Lisbon Treaty due to the presumed lack of necessity for such coordination. ${ }^{72}$ Furthermore, COSAC publishes biannual reports and the national parliaments' replies to comprehensive questionnaires on a variety of topics of direct relevance for European scrutiny. These reports are particularly useful as they provide not only information but often also reflections by the actors directly involved in the scrutiny of EU affairs. As such, they can be a valuable research tool.

\subsubsection{Subsidiarity checks}

To date, COSAC has conducted a total of eight coordinated subsidiarity checks, which are specified in the table below.

Table 1 - List of subsidiarity checks

\begin{tabular}{|c|c|c|c|}
\hline & Proposal name & $\begin{array}{c}\text { No of } \\
\text { chambers } \\
\text { detecting } \\
\text { breach(es) }\end{array}$ & $\begin{array}{c}\text { No of } \\
\text { participating } \\
\text { chambers } \\
\text { within deadline }\end{array}$ \\
\hline 1. & $\begin{array}{l}3^{\text {rd }} \text { Railway Package: } \\
\text { - Regulation on compensation in cases of } \\
\text { non-compliance with contractual quality } \\
\text { requirements for rail freight services } \\
\text { - Directive on the certification of train crews } \\
\text { operating locomotives and trains on the } \\
\text { Community's rail network } \\
\text { - Council Directive on the development of } \\
\text { the Community's railways }\end{array}$ & $\begin{array}{l}5 \\
3\end{array}$ & 31 \\
\hline 2. & $\begin{array}{l}\text { Council Regulation amending Regulation } \\
\text { (EC) No } 2201 / 2003 \text { as regards jurisdiction } \\
\text { and introducing rules concerning applicable } \\
\text { law in matrimonial matters, COM(2006) } 399 \\
\text { final of } 17 \text { July } 2006\end{array}$ & $\begin{array}{l}5 \text { (B Senate, } \\
\text { NL TK\&EK, } \\
\text { UK Lords, } \\
\text { CZ Senate) }\end{array}$ & 11 \\
\hline
\end{tabular}

${ }_{71}$ Matthieu Houser, 'La COSAC, une instance européenne à la croisée des chemins' (2005) 2 Revue du Droit de l'Union Européenne 357.

72 A former permanent member of the COSAC Secretariat and the current senior adviser in the Secretariat General of the Lithuanian Parliament, Loreta Raulinaityte, opined that the discontinuation was premature, since it had provided a cohesive tissue that tied national parliamentary reactions to a more or less unified schedule. Oral presentation at the conference 'Parliaments in the European Union after Lisbon', Maastricht, 23-24 February 2012. 


\begin{tabular}{|c|c|c|c|}
\hline \multicolumn{2}{|r|}{ Proposal name } & \multirow{2}{*}{$\begin{array}{c}\text { No of } \\
\text { chambers } \\
\text { detecting } \\
\text { breach(es) }\end{array}$} & \multirow{2}{*}{\begin{tabular}{|c|} 
No of \\
participating \\
chambers \\
within deadline \\
10
\end{tabular}} \\
\hline 3. & $\begin{array}{l}\text { Directive of the European Parliament and of } \\
\text { the Council } \\
\text { amending Directive } 97 / 67 / \text { EC concerning } \\
\text { the full accomplishment of the internal } \\
\text { market of Community postal services, } \\
\text { COM(2006) } 594 \text { final of } 18 \text { October } 2006\end{array}$ & & \\
\hline 4. & $\begin{array}{l}\text { Council Framework Decision amending } \\
\text { Framework Decision 2002/475/JHA on } \\
\text { combating terrorism COM(2007) } 650 \text { final of } \\
6 \text { November } 2007\end{array}$ & $\begin{array}{c}1 \text { (UK } \\
\text { Commons) }\end{array}$ & 25 \\
\hline 5. & $\begin{array}{l}\text { Council Directive on implementing the } \\
\text { principle of equal treatment between } \\
\text { persons irrespective of religion or belief, } \\
\text { disability, age or sexual orientation, } \\
\text { COM(2008) } 426 \text { final of } 2 \text { July } 2008 \\
\end{array}$ & $\begin{array}{c}2 \text { (IE } \\
\text { Oireachtas) }\end{array}$ & 17 \\
\hline 6. & $\begin{array}{l}\text { Directive of the European Parliament and of } \\
\text { the Council } \\
\text { on standards of quality and safety of } \\
\text { human organs intended for transplantation, } \\
\text { COM(2008) } 818 \text { of } 8 \text { December } 2008\end{array}$ & $\begin{array}{c}1 \text { (AT } \\
\text { Bundesrat) }\end{array}$ & 27 \\
\hline 7. & $\begin{array}{l}\text { Council Framework Decision on the right to } \\
\text { interpretation and to translation in criminal } \\
\text { proceedings, COM(2009) } 338 \text { final of } 8 \text { July } \\
2009\end{array}$ & $\begin{array}{l}4 \text { (AT } \\
\text { Bundesrat, } \\
\text { IE } \\
\text { Oireachtas } \\
\text { \& Malta) } \\
\end{array}$ & 21 \\
\hline 8. & $\begin{array}{l}\text { Regulation of the European Parliament and } \\
\text { of the Council on jurisdiction, applicable } \\
\text { law, recognition and enforcement of } \\
\text { decisions and authentic instruments in } \\
\text { matters of succession and the creation } \\
\text { of a European Certificate of Succession, } \\
\text { COM(2009)154 final of } 14 \text { October } 2009\end{array}$ & 1 (B Senate) & 36 \\
\hline
\end{tabular}

Source: COSAC subsidiarity check reports ${ }^{73}$

The data presented in Table 1 demonstrates that, with the exception of the $3^{\text {rd }}$ Railway Package, which was the first pilot project, national parliaments have as a rule found a negligible number of subsidiarity breaches. According to COSAC reports on subsidiarity checks, national parliaments mostly experience the following difficulties or problems in the course of subsidiarity assessment:

73 See COSAC < http://www.cosac.eu/en/info/earlywarning/> accessed 3 March 2012. 
- Lack of sufficient arguments justifying the proposals in terms of subsidiarity;

- Lack of official translation into all the languages of the EU Member States;

- Time constraints regarding the deadline for submission of reactions (currently 8 weeks);

- Distinguishing between subsidiarity and proportionality; and

- Lack of interparliamentary cooperation in order to know about the results of scrutiny in other national parliaments.

These cursory findings on the functioning of subsidiarity monitoring by national parliaments can be interpreted in a twofold manner. On the one hand, they exhibit the inability of domestic parliamentarians to adapt to the rules of the post-Lisbon multilevel decision-making game both in organisational terms (eg meeting the deadline, accessing the right language version of the text, etc) and in substantive terms (eg the inability to differentiate between the principles that may be challenged), but this is not surprising given the novelty of the procedure. On the other hand, this could mean that the Commission uses its legislative and policy-making powers judiciously and that it as a rule meets the expectations of a majority of national parliaments. The latter is prone to fortify the democratic legitimacy of the resulting EU decisions to a certain extent.

Bearing in mind the outcomes of the coordinated subsidiarity checks and the very high thresholds necessary to oblige the Commission to alter its proposals, it seems that the subsidiarity guardianship role of national parliaments should best be understood as a catalyst for a more comprehensive scrutiny of EU policy. ${ }^{74}$ Restricting scrutiny only to subsidiarity threatens to drag the attention of MPs and senators away from evaluating the policy routes suggested by the Union, the action of the national government and the substantive policy dialogue among EU institutions.

74 Philipp Kiiver, 'The Treaty of Lisbon, the National Parliaments, and the Principle of Subsidiarity' (2008) 15 Maastricht Journal of European and Comparative Law 82. 


\subsection{The Barroso Initiative: narrowing the gap with national parliaments}

\subsubsection{Origin and functioning of the Barroso Initiative}

As explained elsewhere in greater detail, ${ }^{75}$ in May 2006 the Commission announced its intention to transmit all new proposals and consultation papers, such as Green and White Papers, directly to national parliaments. In order to streamline the EU policy-making process, the latter were invited to send their reactions, opinions and other political considerations to the Commission. ${ }^{76}$ This was endorsed at the June 2006 European Council meeting:

The European Council notes the interdependence of the European and national legislative processes. It therefore welcomes the Commission's commitment to make all new proposals and consultation papers directly available to national parliaments, inviting them to react so as to improve the process of policy formulation. The Commission is asked to duly consider comments by national parliaments - in particular with regard to the subsidiarity and proportionality principles. National parliaments are encouraged to strengthen cooperation within the framework of the Conference of European Affairs Committees (COSAC) when monitoring subsidiarity. ${ }^{77}$

The Barroso Initiative has been operational since September 2006. It is a broad political dialogue between the Commission and national parliaments on all aspects of the former's legislative agenda. The Initiative primarily encompasses the invigilation by national parliaments of the Commission's compliance with the principles of subsidiarity, proportionality, conferral and political accountability. The involvement of national parliaments in the political enforcement of these cornerstone EU principles is an important, albeit rudimentary, element of an evolving multilevel system of EU representative democracy. To wit, whereas control over the principle of conferral ensures that the EU possesses the competence to act, control over the principles of subsidiarity, proportionality and political accountability ensures that the EU uses its existing competence in harmony with the conditions agreed between the Member States as Masters of the Treaties. The Barroso Initiative furthermore allows national parliaments to assess any other legal and political aspect of proposed EU legislation, such as the opportuneness and desirability

\footnotetext{
75 Davor Jančić, 'The Barroso Initiative: Window Dressing or Democracy Boost?' (2012) 8 Utrecht Law Review 78.

76 European Commission, Communication 'A Citizens' Agenda: Delivering Results for Europe' COM (2006) 211, 10 May 2006, 9.

77 Presidency Conclusions, Brussels European Council of 15-16 June 2006, para 37.
} 
of action. All of this is done by examining the substance of draft EU acts and the Commission's instruments of legislative planning, the most significant of which are annual policy strategies and legislative and work programmes.

The Initiative functions in two main modes: (a) in the early phase of the Commission's policy-making cycle in order to impart national concerns to its draft legislative proposals; and (b) at any other time through a motley array of visits to national parliaments by Commission officials, meetings with national parliamentary committees and permanent parliamentary representatives to the EU, and gatherings in various interparliamentary forums.

\subsubsection{The political dialogue in practice}

Since the initiation of the Barroso Initiative, the political dialogue with national parliaments has intensified. In the period from 1 January 2005 to 31 December 2008, the Commission had a total of 521 contacts with national parliaments. In addition, from September 2006 to June 2012, the Commission received a total of 2,027 opinions from national parliaments, including those within the early warning mechanism. ${ }^{78}$ In 2011 alone, which is the last reporting year, the Commission received a total of 622 opinions, which is an increase of some $60 \%$ compared to 2010. These data testify to growing interest among national parliamentarians in political dialogue on EU policies.

An EU proposal that elicited a significant number of reactions was the Seasonal Workers' Directive. ${ }^{79}$ This Proposal received a total of 16 opinions, of which nine reasoned opinions found a subsidiarity breach. ${ }^{80}$ By way of example, we will examine the opinions on this proposal submitted by the parliamentary chambers of the Czech Republic, Germany, Spain, Italy and the Netherlands. These were chosen to take into account a geographical variety of the Member States (encompassing west-

\footnotetext{
78 European Commission, Annual report 2009 on relations between the European Commission and national parliaments COM (2010) 291, 2 June 2010, 2; European Commission, Annual report 2010 on relations between the European Commission and national parliaments, COM (2011) 345, 10 June 2011, 5; European Commission, Annual report 2011 on relations between the European Commission and national parliaments COM (2012) 375, 10 July 2012, 4.

79 Proposal for a Directive of the European Parliament and of the Council on the conditions of entry and residence of third-country nationals for the purposes of seasonal employment COM (2010) 379 of 13 July 2010.

80 See additional information on the national parliamentary scrutiny activities regarding this Proposal at <http://www.ipex.eu/IPEXL-WEB/dossier/document/COM20100379FIN. do $>$ accessed 10 March 2012. See also <http://ec.europa.eu/dgs/secretariat_general/relations/relations_other/npo/index_en.htm> accessed 10 March 2012.
} 
ern, central and southern Europe) but also to present the diversity of national parliamentary reactions within the framework of the Barroso Initiative. The other Member States that sent their opinions and views on this Proposal were the British House of Commons and House of Lords, the Portuguese Assembleia da República, the Austrian Nationalrat and Bundesrat, the Polish Sejm and Senate, the Latvian Saeima and the Lithuanian Seimas.

\section{A) The Czech Republic}

After hearing the $1^{\text {st }}$ Deputy Minister for Internal Affairs and the Director of the International Cooperation Department of the Ministry of Labour and Social Affairs, the European Affairs Committee of the Czech Chamber of Deputies adopted on 7 October 2010 a resolution containing a reasoned opinion on subsidiarity infringement. This is due to the fact that 'the situation of third-country nationals who really consider a seasonal work in the Czech Republic can be tackled according to the legislation in force'. Furthermore, the Czech MPs found that the Proposal brought no added value because of the differences in the forms of seasonal or other short-term work across the EU. ${ }^{81}$ No further substantiation was offered about the reasons why subsidiarity was deemed to be breached. In its reply, the Commission provided a comprehensive overview of its comments on the objections and considerations of all other national parliaments, which was to address the Chamber's concerns. ${ }^{82}$

Similarly, albeit in slightly greater detail, the Czech Senate passed a resolution on 22 June 2010 detecting a subsidiarity violation. The senators were of the opinion that the conditions of entry and residence of seasonal workers 'can be adequately regulated on the national level, while legal regulation on the EU level is neither necessary nor does it present an added value when compared to the current state, with regard to its extent and impacts'. ${ }^{83}$ However, the senators went further to comment on the substance of the Proposal. In this vein, they emphasised, inter alia: (a) that the need for regulating seasonal work differs across the Member States due to different structures of their labour markets; (b) that the Proposal contains no effective mechanism to prevent third-country

\footnotetext{
81 See Parliament of the Czech Republic, the Chamber of Deputies <http://ec.europa. $\mathrm{eu} / \mathrm{dgs} /$ secretariat_general/relations/relations_other/npo/docs/czech_republic/2010/ com20100379/com20100379_deputies_opinion_en.pdf> accessed 5 March 2012.

82 See European Commission <http://ec.europa.eu/dgs/secretariat_general/relations/relations_other/npo/docs/czech_republic/2010/com20100379/com20100379_deputies_reply_en.pdf> accessed 5 March 2012.

83 See Parliament of the Czech Republic, the Senate <http://ec.europa.eu/dgs/secretariat_general/relations/relations_other/npo/docs/czech_republic/2010/com20100379/ com20100379_senate_opinion_en.pdf> accessed 5 March 2012.
} 
nationals who seek to ensure EU residence beyond six months from applying for a residence permit in another Member State once their original permit expires; (c) that laying down rules on circular migration should not be restricted to specific sectors, such as agriculture or tourism, but should include other sectors such as the building industry; (d) that the Proposal might lead to seasonal workers enjoying a higher level of protection in the area of social welfare than nationals of the new Member States where the transitional periods regarding access to labour markets still apply; (e) that it is not possible precisely to identify the financial impacts of the guarantees that should be granted to seasonal workers in the area of social welfare; and (f) that the Proposal leads to new administrative costs.

The Commission sent the same reply as it did to the Czech MPs. In it, it addressed several of the senators' points. It agreed that the demand for third-country seasonal workers varies among the Member States and pointed out that this had been stated in its impact assessment. To take account of the domestic specificities, the Proposal envisaged the right of the Member States to decide the number of seasonal workers they admit, to apply a labour market test and to determine which sectors of the economy fall under seasonal work. Concerning the possibility of seasonal workers seeking residence in other Member States after the expiry of the six-month period, the Commission stressed that it was indeed its express intention to allow third-country nationals to find a second seasonal job, as the opposite solution would be unnecessarily restrictive for both employers and employees and would create additional burdens for the Member States. The Commission also underlined that a recital from the Proposal enshrines the principle of equal treatment and excludes the possibility of more rights being conferred to seasonal workers than what is already provided in the existing EU legislation. ${ }^{84}$

\section{B) Germany}

While the Bundestag remained silent, the Bundesrat adopted a resolution on the Proposal on 24 September 2010 in accordance with the Act on Cooperation between the Federation and the Länder in Matters Relating to the European Union. ${ }^{85}$ This resolution did not address the question of subsidiarity compliance but focused entirely on the substance of

\footnotetext{
84 This explanation, in the view of this author, does not adequately address the Czech senators' concern, because no differentiation is made between EU citizens from Member States that are subject to labour market access restrictions and those from Member States without such restrictions.

85 See Parliament of Germany, Bundesrat <http://ec.europa.eu/dgs/secretariat_general/relations/relations_other/npo/docs/germany/2010/com20100379/com20100379_ bundesrat_opinion_en.pdf> accessed 5 March 2012.
} 
the Proposal. The members of the Bundesrat assessed that the existing legal arrangements governing the seasonal employment of third-country nationals is well balanced and flexible and that at most only a small adjustment was required. The Federal Government should therefore make sure that the Proposal does not contradict the current German legal framework and that it does not go beyond what is necessary to achieve its objectives. The latter is aimed at safeguarding the principle of proportionality. The resolution, moreover, recommended the adoption of several amendments to the Proposal and called on the Federal Government to assert them in negotiations at the EU level. The proposed amendments suggest, among other things: (a) that the envisaged processing time for residence permit applications of 30 days is unjustifiably short and that it should be extended to 90 days; (b) that non-decision by the competent national authorities within the deadline should lead neither to the constructive approval of the permit nor to the right to compensation; (c) that the simplified re-entry procedure is not welcome since it might lead to abuses; (d) that a rule should be introduced that residence permits would apply only to the Member State in which they are issued; (e) that family reunification should be expressly excluded; and (f) that statistics keeping duties of the Member States should be reduced. The Commission sent a response to most of these concerns. ${ }^{86}$ It stated that the short application processing time is needed to ensure the attractiveness of the scheme, to allow employers speedy access to the workforce and to communicate the decision to the applicant as soon as possible. Then, it reassured the Bundesrat that the consequences of non-decision within the deadline would be regulated by national law. The Commission furthermore iterated that instead of the simplified re-entry procedure, the Member States may opt for multi-seasonal permits. The statistics requirement is necessary for proper evaluation of the functioning of the proposed legal framework.

\section{C) Spain}

After examining the negative opinions of the Czech and Austrian parliaments, the Joint Committee for the European Union of the Spanish Parliament, Cortes Generales, adopted a report on 28 September 2010 deciding that the Proposal was nonetheless in harmony with the principle of subsidiarity, primarily because most Member States need temporary workers from third countries and because it helps combat illegal

\footnotetext{
86 See European Commission <http://ec.europa.eu/dgs/secretariat_general/relations/ relations_other/npo/docs/germany/2010/com20100379/com20100379_bundesrat_reply_en.pdf $>$ accessed 5 March 2012.
} 
immigration. ${ }^{87}$ The Proposal was also found to be in conformity with the principle of proportionality, because it leaves the Member States sufficient flexibility in implementing it while at the same time avoiding the enactment of extremely complex and bureaucratic norms. The legal basis of the proposal was validated, too. Further, the Proposal was assessed as beneficial for all the parties concerned, since it provides guarantees and security and defines the terms and conditions for the salaries and social protection of seasonal workers. In the Spanish parliamentarians' eyes, the Proposal also respects the Member States' right to determine the caps on the admission of third-country nationals. The Commission did not send a reply, most probably because the Spanish Parliament's opinion was favourable.

D) Italy

Taking into account the standpoint of the Committee for European Union Policies, the Italian Lower House, Camera dei Deputati, adopted a favourable opinion on the Proposal. ${ }^{88}$ The latter was judged justified because it responds to a real demand for workforce that raises clear transnational issues. While praising the merits and approving the Proposal, the MPs invited the Government to advocate adequate discretion in the implementation of the rules in order to provide the Member States with the flexibility needed to accommodate the specific characteristics of each economic system. For instance, an extension of the maximum duration of seasonal work permits beyond six months would benefit the Italian agricultural sector. The Chamber of Deputies also recommended an assessment of the advisability of a more detailed regulation of penalties for employers who do not fulfil their obligations, then of the consequences of granting more extensive social security rights to seasonal workers than what the national law provides, and of adding 'threats to national security' as one of the grounds for refusing or revoking seasonal work permits so as to prevent the entry of potentially dangerous individuals. The Commission's reply tackled some of the MPs' suggestions. ${ }^{89}$ In relation to the duration of stay of seasonal workers, the Commission underlined that the six-month period was agreed after careful consideration of possible

\footnotetext{
87 See Parliament of Spain, Cortes Generales <http://ec.europa.eu/dgs/secretariat_general/relations/relations_other/npo/docs/spain/2010/com20100379/com20100379_both_ opinion_es.pdf> accessed 5 March 2012.

88 See Parliament of Italy, the Chamber of Deputies <http://ec.europa.eu/dgs/secretariat general/relations/relations_other/npo/docs/italy/2010/com20100379/com20100379_ deputati_opinion_en.pdf> accessed 8 March 2012.

89 See European Commission <http://ec.europa.eu/dgs/secretariat_general/relations/relations_other/npo/docs/italy/2010/com20100379/com20100379_deputati_reply_en.pdf> accessed 8 March 2012.
} 
options and national legislative solutions. This maximum period was chosen with a view to balancing the goal of enabling employers to access the needed workforce with that of ensuring that year-long jobs are not filled with third-country seasonal workers. Concerning the sanctioning of employers, the Commission explained that the concretisation thereof was left to the Member States in the spirit of subsidiarity. This exchange of views was followed by another discussion round between the Chamber and the Commission.

For its part, the Italian Senato della Repubblica - through the opinions of the Committee for European Union Policies, the Committee on Labour and Social Security and the Committee for Foreign Affairs and Emigration - expressed the view that, despite detailed regulation, the Proposal conformed to the principles of both subsidiarity and proportionality. ${ }^{90}$ Two further points were highlighted by all three committees: (a) the 30-day deadline for processing applications for seasonal work permits might be burdensome for Italian administration to adapt to; and (b) the maximum period of stay of six months might not meet the needs of the Italian agricultural sector. To these senators' concerns, the Commission responded with the same comments as those given to the German Bundesrat on the time permitted to process applications for seasonal work permits and those given to the Chamber of Deputies on the duration of stay of seasonal workers. ${ }^{91}$

\section{E) The Netherlands}

On 14 October 2010, the Dutch Parliament, Staten-Generaal, informed the Commission of the 'subsidiarity test' it had carried out regarding this Proposal. By means of a joint opinion, both chambers, the Tweede Kamer (Lower House) and the Eerste Kamer (Upper House), found that the principles of both subsidiarity and proportionality had been infringed. ${ }^{92}$ The Dutch MPs and senators disagreed with the Commission's appraisal that the demand for seasonal workers is at a similar level in the Member States. In their view, the Commission's stance was based on unclear figures. Instead, large variations existed in the national labour markets regarding job seekers. Since the Commission failed to demon-

\footnotetext{
90 See Parliament of Italy, the Senate <http://ec.europa.eu/dgs/secretariat_general/relations/relations_other/npo/docs/italy/2010/com20100379/com20100379_senato_opinion_en.pdf> accessed 8 March 2012.

91 See European Commission <http://ec.europa.eu/dgs/secretariat_general/relations/relations_other/npo/docs/italy/2010/com20100379/com20100379_senato_reply_en.pdf> accessed 8 March 2012.

92 See Parliament of the Netherlands, the House of Representatives and the Senate <http://ec.europa.eu/dgs/secretariat_general/relations/relations_other/npo/docs/netherlands/2010/com20100379/com20100379_both_opinion_en.pdf> accessed 9 March 2012.
} 
strate that differences between the Member States and regions are due to different legislative approaches, there was no clear need for the Proposal. Furthermore, the two parliamentary chambers underscored that the problem of seasonal workers overstaying their work permits could be better tackled by enhancing the capacity of and collaboration between national supervisory and inspection organisations than by harmonising laws and regulations. The Dutch parliamentarians thus assessed that national socio-economic laws, together with European and global agreements, sufficiently safeguard the rights of third-country nationals on the EU territory. In addition, the Proposal adds no value in relation to the conclusion of joint agreements with countries of origin regarding seasonal employment, which could represent a way to combat illegal immigration. The Proposal also does not increase the effectiveness of the fight against illegal employment, because it does not require separate work permits for seasonal work shorter than three months. Another contested point was the six-month period as the maximum duration of seasonal employment, which the MPs and senators deemed too long and conducive to abuses of national social security systems. As was the case with the Czech Parliament, the Commission replied with an overview of its reactions to national parliamentary opinions. ${ }^{93}$ Among them was a response that harmonised rules on migration not only facilitate the EU's cooperation with third countries but also potentially have a significant impact on its development policy. The concept of circular migration can actually produce 'triple win' outcomes insofar as the country of destination can meet its workforce needs, seasonal workers bring expertise, knowledge and money back to their country of origin, which in turn is beneficial for the latter country. The Commission also stressed that the Proposal does not ban the Member States from requiring work permits for stays shorter than three months but only that it requires such permits to be issued for stays exceeding this period. The reply concerning varying domestic labour market conditions was identical to that given to Czech senators, whereas the reply concerning the duration of stay of seasonal workers was identical to that given to Italian MPs.

The foregoing examination of the practical participation of national MPs and senators in the Barroso Initiative allows several observations to be made. First, a general remark is that upper chambers appear more proactive and eager to engage in policy discussions with the Commission. This can be explained by the specific constitutional position of these chambers as 'chambers of reflection' rather than as 'chambers of decision'. The accountability link with the national government is mostly

93 See European Commission <http://ec.europa.eu/dgs/secretariat_general/relations/ relations_other/npo/docs/netherlands/2010/com20100379/com20100379_both_reply_ en.pdf> accessed 9 March 2012. 
looser with upper chambers than with lower chambers, which affords the former greater leeway to delve more deeply into the political dialogue with EU institutions. Second, the approach to responding to the Commission's proposals is by no means uniform. While some parliamentary chambers gauge compliance with both subsidiarity and proportionality (eg the Dutch Staten Generaal, the Spanish Cortes Generales and the Italian Senato della Repubblica), others also assess the legal basis (eg the Spanish Cortes Generales) or focus on the substance of the proposal exclusively (eg the German Bundesrat) or predominantly (eg the Czech Senate). Third, the analysis shows that substantive elements of EU proposals are of greater legal and political significance to national parliamentarians than isolated subsidiarity verifications. In this respect, parliaments keenly suggest amendments to draft EU legislation, some of which are aimed at shielding national law (eg the Italian Parliament) and some also at safeguarding the coherence of EU law (eg the German Bundesrat). The Barroso Initiative therefore offers an opportunity for national parliaments to voice the specificities flowing from their juridico-political settings and thus raise awareness within the Commission of the needs, preferences and interests of their Member States. The Commission's replies are succinct, if not brief. Nevertheless, they seem to reflect the Commission's self-imposed commitment to heed national parliamentary concerns and recommendations and justify EU policies from the point of view of particular Member States. This may both appease potential political 'unrest' or scepticism in the domestic legislatures but it may also corroborate the legitimacy of EU policy making. In contrast, where the Commission evades replying to certain preoccupations adduced by one or more national parliaments, this could be taken as a delegitimising factor.

\subsection{Early warning mechanism: policing subsidiarity}

\subsubsection{Origin and functioning of the early warning mechanism}

Once envisaged in the failed Constitutional Treaty, ${ }^{94}$ the Lisbon Treaty's Subsidiarity Protocol enshrined a revised version of the early warning mechanism as one of the most important European tasks of

\footnotetext{
94 NW Barber, 'Subsidiarity in the Draft Constitution' (2005) 11(2) European Public Law 197; Pierre-Alexis Feral, 'Retour en force du principe de subsidiarité dans le Traité constitutionnel: de nouvelles responsabilités pour les parlements nationaux et pour le Comité des régions?' (2004) 481 Revue du Marché Commun et de l'Union Européenne 496; Vlad Constantinesco,'Les compétences et le principe de subsidiarité' (2005) 41(2) Revue Trimestrielle de Droit Européen 305; Anna Vergés Bausili,'Beyond the Early Warning Mechanism: The Reform of EU Governance and National Parliaments' in Ingolf Pernice and Jiri Zemanék (eds), A Constitution for Europe: The IGC, the Ratification Process and Beyond (Nomos Verlagsgesellschaft 2005).
} 
national parliaments. ${ }^{95}$ This mechanism charges national parliaments with monitoring the compliance of draft EU legislative acts with the principle of subsidiarity in the field of shared competences. Subsidiarity supervision therefore does not address the question of whether the Union acts ultra vires, ${ }^{96}$ but whether it should use the competence it possesses. Yet it is indeed plausible that in assessing whether subsidiarity has been respected, national parliaments need to take into account the broader context of a given draft EU act.

The early warning mechanism functions as follows. ${ }^{97}$ Within eight weeks, national parliaments may submit reasoned opinions to the presidents of the Commission, the European Parliament and the Council on subsidiarity compliance. The opinions count as votes. Each Member State has two votes, which in non-unicameral systems are apportioned to the houses of parliament or regional assemblies according to national constitutional rules. ${ }^{98}$ There are three stages, which differ as to the threshold of votes and as to the consequence that these trigger.

Stage 1. If the reasoned opinions sent amount to less than a third of the votes allocated to national parliaments, they need to be taken into

95 Protocol no 2 on the Application of the Principles of Subsidiarity and Proportionality. See various analyses: Robert Schütze, 'Subsidiarity After Lisbon: Reinforcing the Safeguards of Federalism?' (2009) 68 Cambridge Law Journal 525; Alexandre Met-Domestici, 'Les parlements nationaux et le contrôle du respect du principe de subsidiarité' (2009) 525 Revue du Marché Commun et de l'Union Européenne 88; René Barents, 'Het subsidiariteitsbeginsel in het Hervormingsverdrag' (2007) 11 Nederlands Tijdschrift voor Europees Recht 253; George Bermann, 'The Lisbon Treaty: The Irish "No". National Parliaments and Subsidiarity: An Outsider's View' (2008) 4 European Constitutional Law Review 453; Ian Cooper, 'The Watchdogs of Subsidiarity: National Parliaments and the Logic of Arguing in the EU' (2006) 44 Journal of Common Market Studies 281; Tapio Raunio, 'Destined for Irrelevance? Subsidiarity Control by National Parliaments' (2010) Elcano Royal Institute, Working Paper No 36/2010; Kiiver, (n 74) 77; Philipp Kiiver, The Early Warning System for the Principle of Subsidiarity: Constitutional Theory and Empirical Reality (Routledge 2012).

96 See contra the view that "compliance with the principle of subsidiarity is not merely a question of how desirable a certain piece of EU legislation is or would be. What is at stake is the question whether the European Union may (lawfully) legislate at all'. Philipp Kiiver, 'The Early-Warning System for the Principle of Subsidiarity: The National Parliament as a Conseil d'État for Europe' (2011) 36 EL Rev 104. This interpretation is questionable, because the Union indeed possesses the competence to legislate, but since that competence is shared with the Member States, an assessment, inherently of a political nature, must be made concerning the desirable level at which action should be taken.

97 Article 7 of the Subsidiarity Protocol.

98 This means that unicameral parliaments have two votes. The houses of a bicameral parliament have one vote each. In systems with more than two assemblies, the two votes pertaining to that Member State are allocated in accordance with national constitutional law. For example, Declaration no 51 by the Kingdom of Belgium on national parliaments attached to the Treaty of Lisbon clarifies that 'not only the Chamber of Representatives and Senate of the Federal Parliament but also the parliamentary assemblies of the Communities and the Regions act, in terms of the competences exercised by the Union, as components of the national parliamentary system or chambers of the national parliament'. 
account by the Commission or another institution that initiated a given draft EU act.

Stage 2 (yellow card). If the reasoned opinions amount to at least a quarter of the votes in the Area of Freedom, Security and Justice, or at least $a$ third in all other fields, the Commission must review the draft, whereupon it may decide to maintain, amend or withdraw it. Whatever its decision, the Commission must provide reasons for this.

Stage 3 (orange card). If, in the ordinary legislative procedure, the reasoned opinions amount to a simple majority of the votes allocated, the draft proposal, as in the second stage, must be reviewed, after which the Commission may decide to maintain, amend or withdraw it. If the Commission decides to proceed, it must justify in its own reasoned opinion why it considers that the draft is in conformity with subsidiarity. The Commission must then, unlike in the second stage, send the national parliaments' reasoned opinions, together with its own, to the Union legislature (the Council and the European Parliament) for a final decision. This decision must be taken before the end of the first reading. The draft falls if at least a majority of 55\% of the Council members or a majority of the votes cast in the European Parliament decide that the proposal contravenes subsidiarity. This stage of the early warning procedure did not exist in the Constitutional Treaty, but was added by the Lisbon Treaty. ${ }^{99}$ The high threshold for the rejection of the proposal has rightly been criticised, because if the European Parliament and the Council can muster such massive opposition, the proposal would be rejected anyway during the ordinary legislative procedure, thereby rendering an 'early warning' superfluous. ${ }^{100}$

One ought to distinguish between the so-called 'early warning mechanism' and the Barroso Initiative. ${ }^{101}$ Unlike the Barroso Initiative, the early warning mechanism is foreseen in the Treaties and as such can produce legally binding consequences for EU institutions and can

\footnotetext{
99 See further in: Olaf Tans, 'De oranje kaart: een nieuwe rol voor nationale parlementen?' (2007) 11 SEW - Tijdschrift voor Europees en economisch recht 442; Stefanie Rothenberger and Oliver Vogt, 'The "Orange Card": A Fitting Response to National Parliaments' Marginalisation in EU Decision-making?' Paper prepared for the conference 'Fifty Years of Interparliamentary Cooperation' (Berlin, 13 June 2007). A number of authors indeed fear that the right of veto in the hands of national parliaments would distort the distribution of power in the EU's system of governance and that it would concede too much to national interests. See Stephen Weatherill, 'Using National Parliaments to Improve Scrutiny of the Limits of EU Action' (2003) 28 EL Rev 912; Muriel Le Barbier-Le Bris, 'Le nouveau rôle des parlements nationaux: avancée démocratique ou sursaut étatiste?' (2008) 521 Revue du Marché Commun et de l'Union européenne 497.

100 See Article 294 TFEU (former Article 251 TEC) for the voting thresholds in the ordinary legislative procedure. See also Kiiver (n 74) 81.

101 See more in Jančić (n 75) 82.
} 
be abolished only by an amendment of the Treaties. Therefore, the effects of the early warning mechanism are determined by the Treaties and the success of the mechanism does not depend, as is the case with the Barroso Initiative, on the willingness of the Commission. Furthermore, the early warning mechanism is restricted to the monitoring of the principle of subsidiarity, whereas the Barroso Initiative provides much ampler room for political assessment of EU policies. In practice, the difference between the two systems lies in the fact that, due to the difficulty of reaching the aforesaid thresholds, the Commission will seldom be forced to react to parliamentary opinions in the context of the early warning mechanism, but it will do so in the context of the Barroso Initiative because it has politically undertaken to do so. Besides, national parliaments are more interested in providing feedback on the substance of proposals rather than on matters that are purely related to subsidiarity. ${ }^{102}$ Finally, the Commission publishes separate reports for the Barroso Initiative and for the early warning mechanism.

\subsubsection{The early warning mechanism in practice}

For the first time after the entry into force of the Lisbon Treaty, national parliaments reached the 'yellow card' threshold regarding the so-called Monti II Regulation, ie the Proposal for a Council Regulation on the exercise of the right to take collective action within the context of the freedom of establishment and the freedom to provide services. ${ }^{103} \mathrm{~A}$ total of 19 votes, one above the threshold, coming from the parliamentary chambers of 12 Member States - namely Belgium, Denmark, France, Finland, Latvia, Luxembourg, Malta, Poland, Portugal, Sweden, the United Kingdom and the Netherlands - found a subsidiarity violation. ${ }^{104}$ The Commission is now obliged to review its Proposal and decide whether to maintain, amend or withdraw it. In any case, it must justify its decision. As examples, we examine below the reasoned opinions of the parliaments of Belgium, France, Denmark and Malta to take into account the

\footnotetext{
102 European Commission, Annual report 2010 on relations between the European Commission and national parliaments COM (2011) 345, 10 June 2011, 5.

103 European Commission, Proposal for a Council Regulation on the exercise of the right to take collective action within the context of the freedom of establishment and the freedom to provide services COM (2012) 130 of 21 March 2012. See comments on it in Niklas Bruun and Andreas Bücker, 'Critical Assessment of the Proposed Monti II Regulation - More Courage and Strength Needed to Remedy the Social Imbalances' (2012) ETUI Policy Brief no $4 / 2012$.

104 For more information, see IPEX <http://www.ipex.eu/IPEXL-WEB/dossier/document/ COM20120130.do> accessed 3 September 2012. Parliaments sometimes also send positive reasoned opinions that conclude in favour of subsidiarity compliance. This was the case, for example, with the Italian Senato della Repubblica.
} 
geographical representation of the Member States as well as their size and date of accession.

\section{A) Belgium}

By means of the opinion that the Social Affairs Committee adopted on 22 May 2012, the Belgian House of Representatives found a subsidiarity breach and thus filed one vote against the Monti II Regulation. ${ }^{105}$ The breach was based on several grounds. First, the MPs found that the Commission could not use the so-called flexibility clause laid down in Article 352 TFEU as the legal basis for this Proposal. ${ }^{106}$ Second, in their view, the right to work remains a national matter par excellence, even though they agree that the EU may play a complementing or supporting role in this field. Third, they objected to the fact that the draft Regulation foresees the possibility of restricting the right to collective action, as it goes beyond what is authorised by the European Social Charter, which is a treaty guaranteeing social and economic human rights that was concluded in 1961 under the auspices of the Council of Europe.

\section{B) France}

On the same day as the Belgian House of Representatives, the French Sénat adopted a European resolution on the Monti II Regulation. ${ }^{107}$ The principle of subsidiarity was found violated for several reasons. First, the legal basis was judged inadequate. The Commission had failed to draw the attention of national parliaments to the fact that this Proposal was initiated by recourse to Article 352 TFEU, which is an express duty of the Commission under this Treaty. ${ }^{108}$ In addition, the same Article prohibits the harmonisation of national laws or regulations where

\footnotetext{
105 See Parliament of Belgium, the House of Representatives <http://ec.europa.eu/dgs/ secretariat_general/relations/relations_other/npo/docs/belgium/2012/com20120130/ com20120130_representants_opinion_fr.pdf> accessed 4 September 2012.

106 Article 352(1) TFEU empowers the Council of Ministers, acting unanimously on a proposal from the Commission and after obtaining the consent of the European Parliament, to adopt the appropriate measures if action by the Union should prove necessary to attain one of the objectives set out in the Treaties and the Treaties have not provided the necessary powers for it.

107 See Parliament of France, the Senate <http://ec.europa.eu/dgs/secretariat_general/ relations/relations_other/npo/docs/france/2012/com20120130/com20120130_senat_ opinion_fr.pdf> accessed 4 September 2012; See also Sénat, Résolution européenne no 119 portant avis motivé sur la conformité au principe de subsidiarité de la proposition de réglement du Conseil relatif à l'exercice du droit de mener des actions collectives of 22 May 2012.
}

108 Article 352(2) TFEU. 
the Treaties exclude such harmonisation. ${ }^{109}$ In this respect, the senators emphasised that the TFEU indeed expressly excludes the possibility of the Union adopting complementing or supporting measures concerning the right to strike, let alone measures leading to the legal harmonisation of this right. ${ }^{110}$ Second, the Proposal was assessed to exceed the competence of the Union for limiting the exercise of the right to strike. However, the senators offered a wording that would respect the principle of subsidiarity. This wording would omit the clause by which 'the exercise of the fundamental right to take collective action, including the right or freedom to strike, shall respect these economic freedoms'.

\section{C) Denmark}

The European Affairs Committee of the Danish Folketing adopted a reasoned opinion against the Monti II Regulation on 3 May 2012.111 The MPs found that this Proposal infringes the subsidiarity principle because it risks disturbing the already well-functioning domestic arrangements in the field of labour law without adding clarity either to the freedom of movement or the right of workers to take collective action. They also saw no need for the Union to intervene in the existing national mechanisms for dispute settlement. Neither did they think that there was any reason for the EU to establish a duty for the Member States to inform the Commission and the other relevant Member States of potential labour disputes. Just as the French Sénat had done, the Danish Parliament invoked the fact the TFEU explicitly excludes the right to strike from the matters in which the EU may act.

D) Malta

In its exceptionally well-argued reasoned opinion of 22 May 2012, the 69-strong Maltese House of Representatives, Kamra tad-Deputati, rejected the Monti II Regulation on several grounds. ${ }^{112}$ In doing so, the MPs carried out a detailed appraisal not only of the very text of the Proposal but also of the Preamble and the impact assessment. Besides questioning the legal basis, the Maltese parliamentarians challenged the Regulation's purported objective of clarifying the exercise of the right to take collective action in the context of economic freedoms in light of the

\footnotetext{
109 Article 352(3) TFEU.

110 Article 153(5) TFEU.

111 See Parliament of Denmark <http://www.ipex.eu/IPEXL-WEB/dossier/files/download/ 082dbcc536f2cbce01371331bf7b0e14.do> accessed 4 September 2012.

112 See Parliament of Malta <http://www.ipex.eu/IPEXL-WEB/dossier/files/download/ 082dbcc537165b8801377507a7c733a5.do> accessed 4 September 2012.
} 
Viking and Laval judgments of the Court of Justice, holding that these judicial decisions are already very clear so that the Regulation does not add any value. They also disagreed with the choice of the legal instrument, stressing that a Regulation would only have been justified if there had been an urgent necessity for an immediate clarification of the standards used by the Luxembourg Court and if such a Regulation indeed provided such clarity, none of which was the case with this Proposal. Of real concern to the MPs was the Commission's intention to 'prevent solutions being unilaterally sought at national level'. In their view, the Regulation would cause 'disproportionate detriment to proper analysis by national authorities' of whether imperative reasons of public interest necessarily, reasonably and proportionately require a restriction on the exercise of the right to take collective action or on the exercise of economic freedoms. In addition, the alert mechanism envisaged by the Proposal contains a whole array of vague legal standards that are open to wide interpretation. The Regulation thus introduces 'outside involvement of highly undetermined, unclear and indeterminable purpose, operation and effect, and capable of seriously affecting the application of the relevant tests'. For these chief reasons, the Maltese Parliament concluded that the Commission's Proposal failed the tests of necessity, appropriateness (or suitability) and proportionality.

This early warning episode is remarkable both as regards its epilogue and as regards the reasoning that the Commission gave for it. On 12 September 2012, the Commission decided to withdraw its Proposal. This was done in the form of an announcement that the Employment Commissioner, László Andor, made to the members of the Employment Committee of the European Parliament. However, the Commission's Spokesman for employment and social affairs, Jonathan Todd, intimated that a legal assessment of the national parliaments' reasoned opinions 'did not lead to the conclusion that the principle of subsidiarity has been breached'. Instead, he added, the Commission abandoned the Monti II Regulation because it was 'unlikely to gather the necessary political support for its adoption'. ${ }^{113}$ Therefore, even though the Commission's reasoning prima facie appears defiant of the national parliaments' collective subsidiarity appraisal, the mere political force of their opposition did play a factor in halting the Proposal. It is important to underline that the Commission could have proceeded with the Proposal despite the objections of national parliamentarians, but it chose not to. As such, the 'yellow card' issued within the framework of the fledgling early warning

113 EurActiv, 'Brussels Drops Plans for EU Law Limiting Right to Strike', 14 September 2012 <http://www.euractiv.com/socialeurope/ec-drops-regulation-right-strike-news-514793> accessed 20 September 2012. 
mechanism thus proved capable of bringing influence to bear on the Commission's use of its legislative initiative.

\section{Conclusion: cross-level interaction and parliamentary representation}

The analysis carried out in this article confirms the hypothesis that national parliamentary scrutiny of EU matters is not necessarily an isolated domestic process, concentrated merely on control over the activities of governments at the EU level. In certain respects, and as documented particularly by the Barroso Initiative and the early warning mechanism, the scrutiny of EU policies conducted at the national level aims to influence, or at least contribute to, interinstitutional developments in the process of crafting legislation of the European Union. In this sense, the Lisbon Treaty's expectation for national parliaments to contribute actively to the good functioning of the Union is beginning to be fulfilled.

While national parliamentary scrutiny of EU affairs is motivated by domestic legal, constitutional and political circumstances, it can be argued that national MPs and senators embrace new avenues of crosslevel communication on EU policies, mostly in order to safeguard the interests of their own Member States and the constituencies where they were elected. This is evidenced by the Barroso Initiative, as the cases studied reveal the parliamentarians' focus on the repercussions of draft EU initiatives for the domestic legal framework. The examples from the practice of the early warning mechanism also testify to the fact that national MPs and senators do not refrain from giving thorough consideration to the contents and merits of draft EU legislation, sometimes suggesting alternative legal solutions. However, as demonstrated by COSAC subsidiarity checks, many obstacles stand in the way of more efficient national parliamentary participation in EU decision-making processes. Even so, parliaments effectively use the instruments envisaged under national law, such as resolutions and reports, to make their voices heard among EU institutions.

National parliaments should therefore be considered to underpin, albeit modestly, the democratic legitimacy of the EU's ex ante policymaking processes. Cooperation within COSAC, the Barroso Initiative, the early warning mechanism and various interparliamentary forums furnish valuable opportunities for national politicians to have a say in making the Union more accountable to its citizens, not least by prompting EU institutions to explain and justify the policy choices made. Pertinent questions remain open, however. There is no reliable toolkit to measure the influence of the pronouncements of national parliaments in EU matters or the degree of the contribution of such activities to a more 
effective implementation of EU acts in national legal orders. The participatory efforts of national parliaments may nevertheless raise awareness among elected representatives of the high degree of interlacement between the EU and the Member States in both legal and political spheres. For example, a very proactive approach of the Portuguese Assembly to the scrutiny of the Commission's initiatives within the Barroso Initiative has led to an incremental entrenchment of the hitherto non-existent culture of oversight over EU decision making. ${ }^{114}$ Another example of a potential catalyst effect on national parliamentary scrutiny of EU policies is the sharp analysis of the Commission's legislative initiative by the Maltese Parliament, the EU's third smallest national parliament after those of Cyprus and Luxembourg. Since reasoned opinions are often shared across national parliaments in an informal manner and through the IPEX network, the arguments provided by the Maltese parliamentarians might inspire similar assessments in other Member States and thus create a wave of reactions in domestic legislatures.

The role of national parliaments in the European constitutional order has most recently been affected by the current euro crisis. The polycentric nature of this order is countenanced inasmuch as domestic parliamentary mechanisms now more than ever form part of it. It remains to be seen, however, what repercussions the ongoing push towards greater fiscal and financial integration will have on the relations between the Union and its Member States as well as between their respective institutions. In any event, the considerations presented in this article permit one to conclude that the development of a system of representative democracy that spreads across levels of governance is becoming an important ingredient of EU democracy.

114 Davor Jančić, 'The Portuguese Parliament: Blazing the Trail to the European Scrutiny Trophy?' (2011) 1 Interdisciplinary Political Studies 104. 
